\title{
Effects of Combined Aggregate Gradation on the Compression Strength and Workability of Concrete using Fineness Modulus
}

\author{
UKALA, DC \\ Department of Civil Engineering, Delta State University, Abraka, P.M.B. 22, Oleh Campus, Nigeria \\ Email: ukalachuks@gmail.com; ukalacd@delsu.edu.ng; Tel: +2348034260181
}

\begin{abstract}
Aggregate gradation (particle size distribution) is a very important part of concrete production hence the need to combine coarse aggregate with fine aggregate in its simplest form. An improperly graded aggregate structure can have undesirable effects on the properties of concrete as it can produce weak, stiff or porous concretes. In this research, the properties of concrete in terms of strength, slump and density were studied by varying aggregate grades. Proportions of $12.7 \mathrm{~mm}, 25.4 \mathrm{~mm}$, and $38.1 \mathrm{~mm}$ and $50.8 \mathrm{~mm}$ sizes of granite as coarse aggregates were varied in order to create diverse coarse aggregate grading and then combined with a constant fine aggregate gradation and a fixed water/cement $(\mathrm{w} / \mathrm{c})$ ratio of 0.7. The results showed that as the coarse aggregate was spread evenly across all four aggregate sizes the strength was maximum as compared to when the aggregates were concentrated towards the $50.8 \mathrm{~mm}$ size. The workability was seen to be stiffer as more coarse aggregate sizes were introduced into the mix. When the $50.8 \mathrm{~mm}$ granite size represented the total coarse aggregate content $(60 \%)$ of the concrete mix, the mix recorded a slump of $40 \mathrm{~mm}$. The workability declined slightly to slumps of $30 \mathrm{~mm}, 20 \mathrm{~mm}$ and $10 \mathrm{~mm}$ when the coarse aggregate content was produced by combining granite sizes of $50.8 \mathrm{~mm}$ and $38.1 \mathrm{~mm} ; 50.8 \mathrm{~mm}, 38.1 \mathrm{~mm}$ and $25.4 \mathrm{~mm}$ and finally $50.8 \mathrm{~mm}, 38.1 \mathrm{~mm}, 25.4 \mathrm{~mm}$ and $12.7 \mathrm{~mm}$ respectively. This indicated that the more coarse aggregate content in the mix the less workable the concrete. Finally the concrete density remained almost constant irrespective of the aggregate grading.
\end{abstract}

DOI: https://dx.doi.org/10.4314/jasem.v23i5.13

Copyright: Copyright $\odot 2019$ Ukala. This is an open access article distributed under the Creative Commons Attribution License (CCL), which permits unrestricted use, distribution, and reproduction in any medium, provided the original work is properly cited.

Dates: Received: 19 October 2018; Revised: 22 March 2019; Accepted 13 April 2019

Keywords: Aggregate, combined aggregate gradation, Fineness Modulus

Aggregates are basic constituents of concrete usually constituting about 75 percent of the volume. The high volume of aggregates in concrete underscores its importance. The grading of fine aggregates (size less than $4.7 \mathrm{~mm}$ ) and coarse aggregates (size greater than $4.7 \mathrm{~mm}$ ) are generally required in concrete production. An aggregate combination made up of more coarse aggregates than fines can lead to the production of porous concrete which in most cases is responsible for damage of properties in buildings through leakages of water and moisture in reinforced concrete members. As a result of this, the approach of aggregate particle size distribution or aggregate gradation (adopted in this work) has become one of the most important characteristics regarding the utilization of aggregates in concrete (Dellarard \& Belloe, 1999). Not only does it influence the material's mechanical properties such as strength and slump, it also affects its durability. At a time it was believed that aggregate gradation had no influence on the strength of concrete and that only the maximum size of the aggregates was of importance. This led research to focus on the effect of the aggregate size on the compressive strength of concrete (Walker \& Bloem, 1960; Bloem \& Gaynor, 1963; Cook, 1989; Zhou, Barr, \& Lydon, 1995;) with results presented as though only one aggregate size was used for the experiment while disregarding the effect of the finer aggregates used in the mix. It was not until Bloem \& Walker (1963) showed that smaller sized graded aggregate with a constant slump and cement content had more strength than larger size graded aggregate, that awareness was directed to the possibility that aggregate gradation was just as important as maximum aggregate size. Most of the earlier works that focused on the effect of aggregate size on the compressive strength of concrete flawed in their methodology as they relied solely on the maximum size of aggregate to draw their conclusions disregarding the fine aggregate content which in itself modified the aggregate gradation of the concrete, a property that could have been responsible for the diverse conclusions reached. Aggregate gradation highly influence the mechanical and durability properties of concrete (Ronnen \& Hashem, 2002; Abdel-Jawad \& Abdullah, 2002; Ergul, Yasin, \& Alaettin, 2004; Sari \& Pasamehmetoglu, 2005; Mucteba, Kemalettin, \& Metin, 2010; Ashraf \& Noor, 2011; Rafat, Paratibha, \& Yogesh, 2012; Zalal, 2012; Ioannis \& Konstantinos, 2013). The most well-known methods of aggregate gradation include using two different segments of 
aggregates (i.e., fine aggregates and coarse aggregates) or using combined aggregate gradation which is coarse aggregate grading combined with fine aggregate gradation (Chenchen et al., 2014). Some studies have shown that the density and strength of concrete can be increased by proper aggregate grading (Chenchen et al, 2014) while others have reported that concrete made from graded aggregates are weaker and less workable than its single sized aggregate concrete counterpart (Ekwulo, 2017) due to a high packing density of the aggregates. The aggregates will then require high cement paste content so as to go in between aggregate interfaces for the concrete to be workable and reach high strengths.

Most mix design methods require the maximum size of aggregates to proportion mix ratios. Only a few methods such as the 0.45 power curve and the coarseness factor chart represents aggregate gradations in concrete design by identifying maximum density gradations with the assumption that a densely graded aggregate concrete will produce a better performing concrete than a less dense graded aggregate concrete. Though it is believed that the denser the concrete the stronger it is, there is no empirical evidence to support that and this is shown typically in the 0.45 power curve where aggregate grades lying directly on the 0.45 most dense line are unworkable and harsh (Talbot and Richart 1923; Walsh, 1933; Besson 1935) and may require a lot of water in the mix. To improve on this and limit the demand of water for the concrete mix, the fineness modulus was propounded as a method of representing the aggregate gradation with the mean size of all the aggregates in the mix (Abrams, 1918; Richardson 2005). This method has been generally accepted as a better approach in representing graded aggregates sizes in concrete production and it's believed that not only does the concrete strength increase with an increase in fineness modulus (Zalal, 2012) but any two or more gradation curve of aggregate that has the same fineness modulus will require the same quantity of water to produce the mix of same plasticity and strength (Zhou, et al., 1995).

This work provides an insight into the use of fineness modulus in understanding and generally predicting the effects of aggregate gradation in concrete as it relates to strength, workability and density. It also shows the distinction between the use of aggregate maximum size and fineness modulus in representing concrete having more than one aggregate size in it.

\section{MATERIALS AND METHODS}

Material preparations and batching: Portland limestone cement grade 42.5 was purchased from a local store and used in this research. The fine aggregate (sand) was gotten from a local river in Oleh, Isoko South Local Government Area, Delta State, Nigeria. The sand had all its sizes pass through the $4.75 \mathrm{~mm}$ sieve and was graded. The outcome of the grading is presented in Table 2. Four sizes of granites were used in varying proportions. These were the $12.7 \mathrm{~mm}(1 / 2 \mathrm{inch})$ size, the $25.4 \mathrm{~mm}$ ( $1 \mathrm{inch})$ size, the $38.1 \mathrm{~mm}$ ( $1.5 \mathrm{inch})$ and finally the $50.8 \mathrm{~mm}$ (2 inch) aggregate sizes.

A Universal Testing Machine with a maximum crushing capacity of $15 \mathrm{kN}$ which was available in the Structural Laboratory of the Department of Civil Engineering, Delta State University, Oleh Campus was used for this work. For a lack of a higher capacity machine, a weak mix ratio of 1:3:6 and a high water/cement ratio of 0.7 was chosen for the concrete in order to ensure the concrete strength fell below $15 \mathrm{kN}$.

The batching was done with respect to the number of cubes that were to be used in the experiment. The tests made up of 4 groups. Each of those groups were tested on 7,14 and 28 days. $100 \mathrm{~mm}$ by $100 \mathrm{~mm}$ by $100 \mathrm{~mm}$ cubes were used and three cubes each were tested on each test day of 7, 14 and 28 days making 9 cubes per group. The batches were calculated in the following manner (Sekar, 2015).

Table 1: Calculations showing batching of the aggregates used for the all groups

\begin{tabular}{|c|c|c|c|c|c|c|c|c|c|c|}
\hline Description & $A D$ & $\mathrm{~V}$ & $\mathrm{NC}$ & WC & $\mathrm{BLtC}$ & TRS & $\mathrm{XCCe}$ & WS & WG & WW \\
\hline Equations & $\begin{array}{l}a= \\
2400\end{array}$ & $\begin{array}{l}b= \\
0.1^{3}\end{array}$ & $\begin{array}{l}c= \\
9\end{array}$ & $\begin{array}{l}\mathrm{D}= \\
\left(\mathrm{a}^{*} \mathrm{~b}\right)^{*}\end{array}$ & $\begin{array}{c}e= \\
c d+(0.1 \% d)\end{array}$ & $\begin{array}{l}\mathrm{f}= \\
1+3+6+0.7\end{array}$ & $\stackrel{g}{=(1 / f) * e}$ & $\begin{array}{l}h= \\
(3 / f)^{*} e\end{array}$ & $\begin{array}{l}I= \\
e(6 / f)^{*} e\end{array}$ & $\begin{array}{l}j= \\
(0.7 / f) * e\end{array}$ \\
\hline Results & 2400 & 0.001 & 9 & 21.6 & 23.76 & 10.7 & 2.22 & 6.66 & 13.32 & 1.55 \\
\hline
\end{tabular}

$A D=$ Assumed Density of concrete $(\mathrm{kg} / \mathrm{m3}) ; \mathrm{V}=$ Volume of one $100 \mathrm{~mm}$ cube. $(\mathrm{m} 3) ; \mathrm{NC}=$ Number of cubes for testing; WC $=$ Weight of 9 cubes $(\mathrm{kg}) ; \mathrm{Wt} . \mathrm{C}=$ Wt. of 9 cubes plus $10 \%$ waste $(\mathrm{kg}) ; \mathrm{TRS}=$ Total ratio sum; WCe = Weight of cement $(\mathrm{kg}) ;$ WS $=$ Weight of sand $(\mathrm{kg})$; $W G=$ Weight of granite $(\mathrm{kg}) ; W W=$ Weight of water $(\mathrm{kg})$

From the calculations in table 1 it can be seen that the total weight by volume of three cube samples for the three test days each was $21.6 \mathrm{~kg}(21600 \mathrm{~g})$. The total volume for the coarse aggregates alone was $13.32 \mathrm{~kg}$ while that of the fine aggregate was $6.66 \mathrm{~kg}$ making a total aggregate volume of $19.98 \mathrm{~kg}(19980 \mathrm{~g})$. 
Aggregate grading methods (groupings): The $6.66 \mathrm{~kg}$ of sand was graded with the use of a mechanical sieve machine and in accordance with the British Standard (BS 3797:1990) from the available sand acquired. The outcome of the fine aggregate grading is shown in table 2. This sand sample was used in group one as the fine aggregate content of the mix. The sand grade was to be kept constant through subsequent groups to maintain the same grade pattern hence minimise or eliminate the effects of a change in sand gradation on subsequent groups. This was done by separating sand retained on each sieve size in different bags. For example to get the size retained on the $2.8 \mathrm{~mm}$ sieve, the $4.75 \mathrm{~mm}$ (which is the size just above the $2.8 \mathrm{~mm}$ sieve) and the $2.8 \mathrm{~mm}$ sieves alone were required. The sand is poured through the $4.75 \mathrm{~mm}$ sieve and whatever passes through the $4.75 \mathrm{~mm}$ sieve but retained on the $2.8 \mathrm{~mm}$ sieve is put in a bag tagged $2.8 \mathrm{~mm}$. This process was carried out for the $2.8,2,1.7,1.18,0.85$, $0.6,0.0425$ and $0.0212 \mathrm{~mm}$ sieves. Having one size grades of fine aggregates bagged per size in this manner made it easy in duplicating the fine aggregate grades in table 2 (group 1) for all other groups. The fine aggregate grade duplication was done by taking the weight required from the sand bag of each size that equals the graded weight of group one and mixing them together. Sieve analysis were also conducted to ensure that the sand grades of other groups tallied with the group one grade.

Table 2: Particle size distribution of the sand specimen

\begin{tabular}{|c|c|c|c|c|c|c|}
\hline $\begin{array}{l}\underset{\mathrm{E}}{\mathrm{E}} \\
\frac{\mathrm{E}}{\mathrm{E}}\end{array}$ & 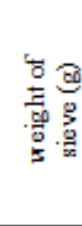 & 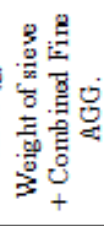 & 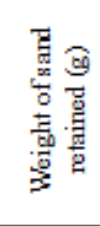 & 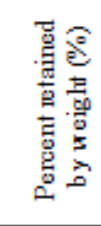 & 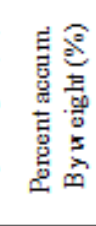 & 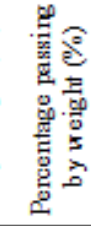 \\
\hline 4.75 & 300 & 300.00 & 0.00 & 0.00 & 0.00 & 100.00 \\
\hline 2.8 & 260 & 497.46 & 237.46 & 3.57 & 3.57 & 96.43 \\
\hline 2 & 250 & 478.35 & 228.35 & 3.43 & 6.99 & 93.01 \\
\hline 1.7 & 210 & 447.46 & 237.46 & 3.57 & 10.56 & 89.44 \\
\hline 1.18 & 200 & 470.36 & 270.36 & 4.06 & 14.62 & 85.38 \\
\hline 0.85 & 200 & 634.76 & 434.76 & 6.53 & 21.15 & 78.85 \\
\hline 0.6 & 200 & 634.76 & 434.76 & 6.53 & 27.68 & 72.32 \\
\hline 0.0425 & 200 & 1950.56 & 1750.56 & 26.28 & 53.96 & 46.04 \\
\hline 0.0212 & 200 & 3266.26 & 3066.26 & 46.04 & 100.00 & 0.00 \\
\hline Base & 110 & 300.00 & 0.00 & 0.00 & 100.00 & 0.00 \\
\hline T OTAL & & & 6660 & 100 & & \\
\hline
\end{tabular}

The coarse aggregates were separated into sizes of $50.8 \mathrm{~mm}, 38.1 \mathrm{~mm}, 25.4 \mathrm{~mm}$ and $12.7 \mathrm{~mm}$ by applying the methods described above and bagged accordingly. Here though, unlike the sand, the coarse aggregates were varied in other to allow for a change in aggregate gradation. Whenever a change in aggregate weight for any sieve size is required, the granite weight required is taken from the bag of that size of granite. For group
1, granite of $50.8 \mathrm{~mm}$ size weighing $13.32 \mathrm{~kg}$ was combined with the sand content already prepared (Table 2). In this group 100 percent of the granite (coarse aggregate) were of the size 50.8 (ie retained at $50.8 \mathrm{~mm}$ sieve but passing through the $63 \mathrm{~mm}$ sieve). In group 2, granite sizes of $50.8 \mathrm{~mm}$ and $38.1 \mathrm{~mm}$ are combined $50 \%$ each $(6.66 \mathrm{~kg}$ each) to make up the $13.32 \mathrm{~kg}$ coarse aggregate content of the mix. Here, granite weighing $6.66 \mathrm{~kg}$ is taken from the bag of $50.8 \mathrm{~mm}$ which is then mixed with $6.66 \mathrm{~kg}$ of granite from the $38.1 \mathrm{~mm}$ bag. These sizes are added to the already prepared sand content (table 2) to get the desired combined aggregate gradation. In group 3, the $13.32 \mathrm{~kg}$ coarse aggregate content is split into three across $50.8 \mathrm{~mm}, 38.1 \mathrm{~mm}$ and $25.4 \mathrm{~mm}$ sieve sizes with granite weights of $4.44 \mathrm{~kg}$ each. Again this was added to the sand volume already prepared (table 2). Finally, in group 4 the coarse aggregates are split into four across the $50.8 \mathrm{~mm}, 38.1 \mathrm{~mm}, 25.4 \mathrm{~mm}$ and $12.7 \mathrm{~mm}$ sieve sizes weighing $3.33 \mathrm{~kg}$ each. This coarse aggregate gradation is combined with the already graded sand (Table 2) as the other groups. The combined gradation of these groups can be seen in figure 1 .

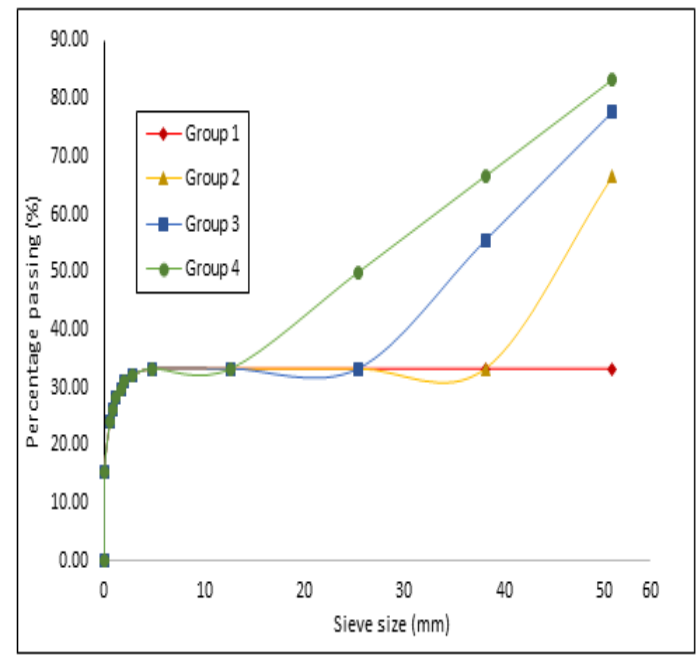

Fig 1: Combined aggregate gradation curves of all groups

The changes in the coarse aggregate proportions was solely responsible for the change in overall aggregate grade. The cement accounted for $10 \%$ of the entire mix. The fine aggregate (sand) accounted for $30 \%$ of the mix and $33.33 \%$ of the total aggregate volume while the coarse aggregate (granite) accounted for $60 \%$ of the entire mix and $66.67 \%$ of the total aggregate volume. This distribution of 1:3:6 ratio was maintained for all the groups used in this work through the methods described so far. 
Finally after combining the fine and coarse aggregates as discussed, the aggregate is then mixed with cement and water of the batched weight (Table 1). Concrete cubes of 100x100x100mm were produced using the moulds and allowed to harden for 24 hours in the moulds. The cubes were then removed from their moulds and transferred to the curing tanks where they were properly tagged and cured. The cubes were totally submerged in water to assist trigger the hydration process and gain sufficient strength. This was where the concrete cubes remained until they were needed for testing at 7,14 and 28 days.

Test carried out and analysis of results: Slump test for the fresh concrete and compressive strength test for the hardened concrete were carried out. The density of the concrete cubes was also determined. The slump test was carried out in accordance with BS EN 123502:2009 while the compressive strength test was carried out in accordance with BS EN 12390-3:2009. All the groups had the same aggregate maximum size of $50.8 \mathrm{~mm}$ but all had different aggregate gradation curves hence the fineness modulus which is the mean size of all the aggregates was used in analysing the results. The fineness modulus was gotten by dividing the sum of all percentage cumulated sizes of the aggregates in a sieve analysis test by 100 (Abrams, 1918; Richardson 2005).

\section{RESULTS AND DISCUSSIONS}

Compressive strength gain, slump and density: Compressive strength increased as the days of curing increased. This was a common factor in all the concrete groups. Groups one (1) and four (4) recorded a slow increase of strength in the concrete from seven to fourteen days then a high increase from fourteen to twenty-eight days. Groups two (2) and three (3) on the other hand had a high increase of strength in the concrete from seven to fourteen days then a low increase rate from fourteen to twenty-eight days, This is shown in the Figure 2.

There was no clear relationship between the aggregate combined gradation of all the groups and the strength of concrete at 7, 14 and 28 days as each group behaved differently. From figure 2, the mix of group 4 (where all aggregate sizes were represented and even), showed a high strength gain at day 7 before the rate of strength gain reduced at the $14^{\text {th }}$ day and finally surpassed all other groups in strength at the $28^{\text {th }}$ day. The reason of the reduction in the rate of strength gain could be as a result of difficulty of free water reaching all the un-hydrated cement due to the compact nature of the aggregate structure. But with further curing up to 28 days, all cement was hydrated leading to a stronger mix. Group 2 and 3 showed a significant strength gain at day 14 and then dropped in the rate of strength gain as the curing approached the $28^{\text {th }}$ day. Here it can be assumed that most of the cement paste had already started the process of hydration at day 14 and had less strength to unlock as the curing reached the $28^{\text {th }}$ day. The gap graded group 1 showed a steady and almost constant rate of strength gain. It however accounted for the lowest strength at the $28^{\text {th }}$ day.

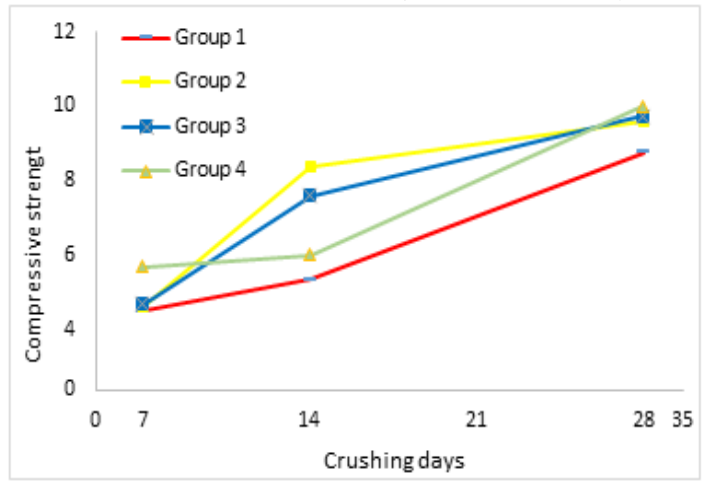

Fig 2: Compressive strength comparison between all concrete mix groups

For the slump test, group 1 mix produced a slump of $40 \mathrm{~mm}$, group 2 had a $30 \mathrm{~mm}$ slump, group 3 was $20 \mathrm{~mm}$ and group 4 slumped by $10 \mathrm{~mm}$. The results are shown in Table 4. The results show that there was a reduction in slump as the coarse aggregate in the concrete became less gap graded and more compact. The more the concrete mix became evenly graded, the less workable the concrete. As the concrete became more compact, the aggregates created a resistance against the flow of other aggregates around them.

The densities of the concrete mixes were taken before and after 28 day curing (just before crushing). The cubes by then had gained additional strengths. The essence of testing for the densities was to observe if the increase in strength led to a change in the density of the concrete. The results of this procedure is presented in Table 3. The results show that there was no significant change in the density of the cubes. This signifies that a gain in strength does not necessarily impact on the density of the cubes.

\begin{tabular}{|c|c|c|c|c|c|c|c|}
\hline \multicolumn{2}{|c|}{ Group 1} & \multicolumn{2}{|c|}{ Group 2 } & \multicolumn{2}{|c|}{ Group 3} & \multicolumn{2}{|c|}{ Group 4} \\
\hline \multicolumn{2}{|c|}{ Average Density kN/m $\mathrm{m}^{3}$} & \multicolumn{2}{|c|}{ Average Density $\mathrm{kN} / \mathrm{m}^{3}$} & \multicolumn{2}{|c|}{ Average Density $\mathrm{kN} / \mathrm{m}^{3}$} & \multicolumn{2}{|c|}{ Average Density $\mathrm{kN} / \mathrm{m}^{3}$} \\
\hline $\begin{array}{l}\text { Before } \\
\text { curing }\end{array}$ & $\begin{array}{l}\text { Before } \\
\text { crushing }\end{array}$ & $\begin{array}{l}\text { Before } \\
\text { curing }\end{array}$ & $\begin{array}{l}\text { Before } \\
\text { crushing }\end{array}$ & $\begin{array}{l}\text { Before } \\
\text { curing }\end{array}$ & $\begin{array}{l}\text { Before } \\
\text { crushing }\end{array}$ & $\begin{array}{l}\text { Before } \\
\text { curing }\end{array}$ & $\begin{array}{l}\text { Before } \\
\text { crushing }\end{array}$ \\
\hline 24 & 24 & $23.8^{\circ}$ & 24 & 24 & 24 & $23.5^{\circ}$ & 23.7 \\
\hline
\end{tabular}

UKALA, DC 
Table 4: Fineness Modulus and maximum aggregate sizes of each group

\begin{tabular}{lllllll}
\multicolumn{7}{c}{ Table 4: Fineness Modulus and maximum aggregate sizes of each group } \\
\hline $\begin{array}{l}\text { Group } \\
\text { number }\end{array}$ & $\begin{array}{l}\text { Fineness } \\
\text { modulus }\end{array}$ & $\begin{array}{l}\text { Aggregate mean } \\
\text { size range }(\mathrm{mm})\end{array}$ & $\begin{array}{l}\text { Maximum } \\
\text { aggregate size }\end{array}$ & $\begin{array}{l}\text { Concrete } \\
\text { strength }\end{array}$ & $\begin{array}{l}\text { Density } \\
\left(\mathrm{kN} / \mathrm{m}^{3}\right)\end{array}$ & $\begin{array}{l}\text { Slump } \\
(\mathrm{mm})\end{array}$ \\
\hline Group 1 & 9.46 & $4.75-12.7$ & $50.8 \mathrm{~mm}$ & $8.77 \mathrm{MPa}$ & 24 & 40 \\
Group 2 & 9.13 & $4.75-12.7$ & $50.8 \mathrm{~mm}$ & $9.6 \mathrm{MPa}$ & 24 & 30 \\
Group 3 & 8.80 & $2.8-4.75$ & $50.8 \mathrm{~mm}$ & $9.73 \mathrm{MPa}$ & 24 & 20 \\
Group 4 & 8.46 & $2.8-4.75$ & $50.8 \mathrm{~mm}$ & $10 \mathrm{MPa}$ & 23.7 & 10 \\
\hline
\end{tabular}

Analysis of results with Fineness modulus: The Universal Testing Machine was used in getting the compressive strength of the concrete. The grades are usually described by the maximum aggregate size or the fineness modulus of the grade. The results will be compared to the fineness modulus of each group as well as the maximum size of each group in other to have a clearer view on the effect of these parameters on concrete property. Table 4 describes these grades under fineness modulus and aggregate maximum size. The more the volume of aggregate retained in the higher aggregate sieve size $(50.8 \mathrm{~mm})$ the coarser the aggregate combination and hence the higher the fineness modulus value. Group 1 had a higher fineness modulus because $100 \%$ of the coarse aggregate content was retained on the $50.8 \mathrm{~mm}$ sieve size. Group 2 had the second highest fineness modulus value because $100 \%$ of the coarse aggregate was shared equally between the $50.8 .8 \mathrm{~mm}$ and the next maximum sieve size of $38.1 \mathrm{~mm}$. Hence as less volume of aggregate was retained on the most coarse sieve sizes, the fineness modulus decreased. Delegating numbers to each sieve size from minimum to maximum such that $0.0212(1), 0.0425(2), 0.6(3), 0.85(4), 1.18(5)$, 1.7(6), 2(7), 2.8(8), 4.75(9), 12.7(10), 25.4(11), 38.1(12) and 50.8(13) indicates that a fineness modulus of 9.46 describes the grade as having an aggregate mean size between the number 9 and number 10 sieves which corresponds to a mean range between $4.75 \mathrm{~mm}$ and $12.7 \mathrm{~mm}$ aggregate size (refer to table 4).

As the fineness modulus increased, the compressive strength decreased meaning that the coarser the aggregate grade the lower the strength which to a large extent corresponds with the findings of Bloem \& Walker (1963). The reduction in strength could be as a result of the gap graded areas in the coarse aggregate section which increased from group 4 to group 1 . Group 1 had no aggregates sizes between $4.75 \mathrm{~mm}$ and $50.8 \mathrm{~mm}$. Group 2 was gap graded between $4.75 \mathrm{~mm}$ and $38.1 \mathrm{~mm}$. Other groups kept reducing in gap grade. This gap in aggregate grades would have created more voids in the concrete than the cement paste could cover. More voids mean less strength. It may be argued that the reduction in strength is as a result of having a stiff concrete mix with the cement paste being insufficient to surround the aggregates and bond them properly since $10 \mathrm{~mm}$ to $40 \mathrm{~mm}$ slumps are considered as concrete with low workability however this argument cannot be substantiated since the concrete strength reduced as the slump increased, if this were to be the case then the opposite response would have been expected. From the results it will be safe to state that the aggregate grades represented by the fineness modulus values had little or no effect in the density of the concrete since the density value remained largely the same through all the groups.

Conclusion: This study shows that concretes of the same mix ratio, maximum size of aggregate and water content will have their strength and workability properties differ if they are subject to a change in aggregate gradation. It shows that as the fineness modulus increases, the concrete becomes weaker but more workable. Finally the density of concrete in not affected by the maximum aggregate size or the grading of aggregates in the mix and could be the reason why the unit weight of mass concrete is usually specified as $24 \mathrm{kN} / \mathrm{m}^{3}$ irrespective of the concrete mix ratio.

\section{REFERENCES}

Abdel-Jawad, YJ; Abdullah, WS (2002). Design of maximum density aggregate grading. Constr. Build. Mater. 16: 495-508.

Abrams, DA (1918). Design of concrete mixtures. Bulletin No. 1, Structural Material Research Laboratory, Lewis Institute, Chicago

ACI (1992) State of the Art Report on High Strength Concrete. ACI Manual of Concrete Practice, 1997 Edition, Part I, Farmington Hills, MI, USA, Report ACI 363R92.

Ashraf, WB; Noor, MA (2011). Performance evaluation of concrete properties for different combined aggregate gradation approaches. Proc. Engr. 14: 2627-2634

Besson, FS (1935). Case against surface area and fineness modulus. Eng. News. Rec. 114(7): 248249.

Bloem, DL; Gaynor, RD (1963) Effects of Aggregate Properties on Strength of Concrete. ACI. J. Proc. 60(10): 1429-1456. 
British Standard Institute. (2009). BS EN 123502:2009. Testing fresh concrete Part 2: Slump-test. London. BSI, London, UK.

British Standard Institute. (2009). BS EN 123903:2009. Compression Strength of Test Specimens. London. BSI, London, UK.

Building Research Institute (2016) Concrete Technology: Gradation of Coarse Aggregates. [Online], Available: http://www.buildingresearch.com.np/services/ct/ ct6.php Assessed: [15 June 2016]

Chenchen, G; Jie, Z; Shoude, W; Wen, Z; Lingchao, L (2014) Effect of Aggregate Gradation with Fuller Distribution on Properties of Sulfoaluminate Cement Concrete. Emerging Binder Materials Conference Proceedings, 4th International Conference on the Durability of Concrete Structures. Purdue University - West Lafayette: $247-253$.

Cook, JE (1989) I0,000 psi Concrete. Concr. Int. 11(10): 67-75.

Dellarard, F; Belloe, A (1999) L'influence du granulat sur la résistance en compression des bétons. Bulletin liason ponts et chausses.

Ekwulo, EO; Eme, DB (2017) Effect of Aggregate Size and Gradation on Compressive Strength of Normal Strength Concrete for Rigid Pavement. Am. J. of Engr. Res. 6(9): 112-116

Ergul, Y; Yasin, E; Alaettin, K (2004). Effect of limestone aggregate type and water-cement ratio on concrete strength. Mater. Let. 58: 772-777.

Ioannis, PS; Konstantinos, GT (2013). Effect of composition variations on bond properties of selfcompacting concrete specimens. Constr. Build. Mater. 41: 252-262.

Jalal, A (2012). Effect of Aggregate on Strength of Concrete [Online]. Available from; http://www.engineeringintro.com/concrete/concr ete-strength/effect-of-aggregates-on-strength-ofconcrete/ Assessed [2 October 2018]
Mucteba, U; Kemalettin, Y; Metin, I (2010). The effect of the initial water to cement ratio on shielding properties of ordinary concrete. Constr. Build. Mater. 52: 491-493.

Rafat, S; Paratibha, A; Yogesh, A (2012). Influence of water/powder ratio on strength properties of selfcompacting concrete containing coal fly ash and bottom ash. Constr. Build. Mater. 29: 73-81.

Richardson, DN (2005). Aggregate gradation optimization-literature search, Univ. of Missouri, Rolla, MO.

Ronnen, L; Hashem, A (2002). Effects of composition and exposure on the solar reflectance of Portland cement concrete. Cement Concrete Res. 32: 1679-1698.

Sari, D; Pasamehmetoglu, AG (2005). The effects of gradation and admixture on the pumice lightweight aggregate concrete. Cement Concrete Res. 35: 936-942.

Sekar, P.K. (2015) Calculate Cement Sand and Aggregate for Nominal mix concrete in Volume and in Weight [Online]. Civil rnd. Available from: http://civilrnd.com/calculate-cement-sandand-aggregate-for-nominal-mix-concrete/

[Assessed: 3rd January, 2019]

Talbot, AN; Richart, FE (1923). The strength of concrete and its relation to the cement, aggregate, water. University of Illinois, Urbana.

Walker, S; Bloem, DL (1960). "Effects of Aggregate Size on Properties of Concrete," ACI. J, Proceedings 57(3): 283-298.

Walsh, HN (1933). Simplified concrete mix design. Am. Concr. Inst. J. 5(2): 110-120.

Zhou, FP; Barr, BIG; Lydon, FD (1995). Fracture Properties of High Strength Concrete with Varying Silica Fume Content and Aggregates. Cement Concrete Res. 25(3): 543-552. 